\title{
Potential of Welan Gum as mud thickener
}

\author{
Changhong Gao
}

Received: 4 February 2014/ Accepted: 5 May 2014/Published online: 25 May 2014

(C) The Author(s) 2014. This article is published with open access at Springerlink.com

\begin{abstract}
Welan Gum (WLG) is a biopolymer employed in food industry as thickener. This paper evaluates its performance as mud thickener and filtrate loss additive. Tests revealed that WLG, even at low concentrations, effectively boosted mud viscosity and yield point. Tests were also conducted on carboxymethyl cellulose (CMC), a commonly used mud thickener. Compared with CMC, WLG is more effective as mud thickener, but WLG has no effect on mud filtrate loss. WLG mud was also tested at elevated temperature. The viscosity of WLG mud was stable under short-term and long-term heating. Sodium chloride and calcium chloride were added into WLG mud. Test results showed WLG mud was resilient to sodium and calcium contamination. WLG has good potential as mud thickener under high temperature and high salinity conditions.
\end{abstract}

Keywords Welan Gum · Drilling mud · Thickener · Salinity

\section{Introduction}

Drilling mud plays a critical role in the success of oil and gas drilling operations. It cools and lubricates drill bit, controls well pressure, transports and suspends cuttings. Mud must have a relatively high viscosity to effectively suspend cuttings. Therefore, mud thickeners are often added into mud to boost mud viscosity. The most widely used mud thickeners are carboxy methyl cellulose (CMC) and hydroxy ethyl cellulose (HEC) (Rabia 1985).

C. Gao $(\bowtie)$

The Petroleum Institute, SINOPEC SLOF, Dongying, China e-mail: 237184689@QQ.COM
Welan Gum (WLG) is produced by fermentation of sugar by bacteria of the genus Alcaligenes. The molecule consists of repeating tetrasaccharide units with single branches of L-mannose or L-rhamnose (Rakitsky and Richey 1992). The molecular structure is presented in Fig. 1. It was reported that WLG exhibits good viscosity retention at elevated temperature, as well as in the presence of sodium chloride (Chen 2007). WLG was patented to be used as cement additive (Allen et al. 1991), as well as water shutoff chemical (Hoskin et al. 1991). However, limited research has been conducted to investigate its effect on mud properties. The objective of this study was to unveil potential of WLG as a mud additive.

\section{Material and method}

Welan Gum was provided by BDL Chemical Company in China. CMC (medium viscosity) was produced by Gumpro Chemical Company in India. Other materials included Bentonite clay, $\mathrm{NaCl}, \mathrm{CaCl}_{2}$, and tap water. Mud viscosity was measured with OFITE 8 -speed viscometer. It measures the torque under 8 different rotational speeds, ranging from 600 to $3 \mathrm{rpm}$. The readings can be easily translated into mud plastic viscosity, mud yield point, and mud apparent viscosity. Mud filtrate was measured with OFITE Model 14030 filter press. Mud passes through a filter paper under $100 \mathrm{psi}$ of pressure, and the filtrate volume after $7.5 \mathrm{~min}$ of filtration is recorded. Pressure is provided by a cartridge containing pressurized carbon dioxide. Mud was prepared with highspeed mixer. The mud viscometer, filter press and mud mixer are all industry-standard devices.

Totally, 23 tests were conducted. The detailed test matrix is given in Tables 1 and 2. First, a base mud was

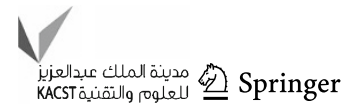


Fig. 1 Molecular structure of Welan Gum

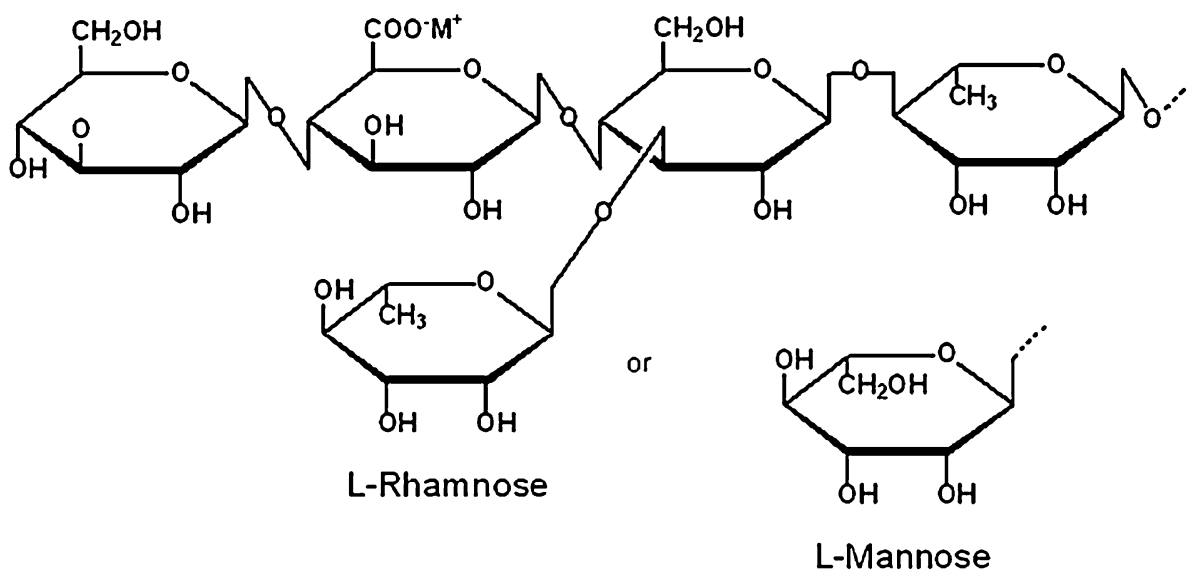

Table 1 Summary of test matrix for WLG mud

\begin{tabular}{llccll}
\hline $\begin{array}{l}\text { Test } \\
\text { no. }\end{array}$ & $\begin{array}{l}\text { Tested } \\
\text { mud }\end{array}$ & $\begin{array}{l}\mathrm{NaCl} \\
(\mathrm{g} / \mathrm{L})\end{array}$ & $\begin{array}{l}\mathrm{CaCl}_{2} \\
(\mathrm{~g} / \mathrm{L})\end{array}$ & $\begin{array}{l}\text { WLG } \\
(\mathrm{g} / \mathrm{L})\end{array}$ & $\begin{array}{l}\text { Temperature } \\
\left({ }^{\circ} \mathrm{C}\right)\end{array}$ \\
\hline 1 & Base mud & 0 & 0 & 0 & 25 \\
2 & WLG mud & 0 & 0 & 0.25 & 25 \\
3 & WLG mud & 0 & 0 & 0.50 & 25 \\
4 & WLG mud & 0 & 0 & 0.75 & 25 \\
5 & WLG mud & 0 & 0 & 1 & 25 \\
6 & WLG mud & 0 & 0 & 1 & 45 \\
7 & WLG mud & 0 & 0 & 1 & 65 \\
8 & WLG mud & 50 & 0 & 1 & 25 \\
9 & WLG mud & 100 & 0 & 1 & 25 \\
10 & WLG mud & 150 & 0 & 1 & 25 \\
11 & WLG mud & 150 & 10 & 1 & 25 \\
12 & WLG mud & 150 & 30 & 1 & 25 \\
13 & WLG mud & 150 & 50 & 1 & 25 \\
14 & WLG mud & 0 & 0 & 1 & $85{ }^{\circ} \mathrm{C}$ for $6 \mathrm{~h}$
\end{tabular}

prepared by mixing $25 \mathrm{~g}$ of clay into $500 \mathrm{~g}$ of fresh water. Then mud viscosity and filtrate were measured. The measurements of mud plastic viscosity (PV), yield point (YP), apparent viscosity (AV) and mud filtrate loss followed textbook and industry standards (Bourgoyne et al. 1986). Second, the effect of WLG concentration on mud viscosity and mud filtrate was investigated by adding different dosages of WLG into the base mud.

The third group of tests was designed to test the performance of WLG mud under the influence of $\mathrm{NaCl}$. Afterward, different dosages of $\mathrm{CaCl}_{2}$ were added to WLG mud and the mud viscosity was measured. Finally, WLG mud was held at $85^{\circ} \mathrm{C}$ for $6 \mathrm{~h}$ to test the effect of aging on mud properties. For the purpose of comparison, CMC was also tested for its stability under the influences of sodium ion, calcium ion, and long-term heating, as given in Table 2 .
Table 2 Summary of test matrix for CMC mud

\begin{tabular}{llrlll}
\hline $\begin{array}{l}\text { Test } \\
\text { no. }\end{array}$ & $\begin{array}{l}\text { Tested } \\
\text { mud }\end{array}$ & $\begin{array}{l}\mathrm{NaCl} \\
(\mathrm{g} / \mathrm{L})\end{array}$ & $\begin{array}{l}\mathrm{CaCl}_{2} \\
(\mathrm{~g} / \mathrm{L})\end{array}$ & $\begin{array}{l}\mathrm{CMC} \\
(\mathrm{g} / \mathrm{L})\end{array}$ & $\begin{array}{l}\text { Temperature } \\
\left({ }^{\circ} \mathrm{C}\right)\end{array}$ \\
\hline 15 & CMC mud & 0 & 0 & 0.5 & 25 \\
16 & CMC mud & 0 & 0 & 1 & 25 \\
17 & CMC mud & 50 & 0 & 1 & 25 \\
18 & CMC mud & 100 & 0 & 1 & 25 \\
19 & CMC mud & 150 & 0 & 1 & 25 \\
20 & CMC mud & 150 & 10 & 1 & 25 \\
21 & CMC mud & 150 & 30 & 1 & 25 \\
22 & CMC mud & 150 & 50 & 1 & 25 \\
23 & CMC mud & 0 & 0 & 1 & $85{ }^{\circ} \mathrm{C}$ for $6 \mathrm{~h}$ \\
\hline
\end{tabular}

\section{Results and analysis}

Figure 2 presents the mud viscosity trends under different shear rates for base mud, as well as mud with WLG. The tests were conducted at room temperature of $25{ }^{\circ} \mathrm{C}$. On this log-log plot, it can be seen that mud viscosity declines almost linearly at higher shear rates. This reveals that mud is a non-Newtonian fluid that abides by the power law (Gao 2013). It is also obvious that even a small dosage of WLG resulted in significant increase in mud viscosity.

Figure 3 presents the effect of WLG on mud YP, PV and AV at ambient temperature. It can be seen that WLG has a significant impact on mud YP and AV. Mud YP and AV steadily increased with increasing concentration of WLG. The mud PV also increased with addition of WLG. It was observed that when WLG concentration increased from 0.75 to $1 \mathrm{~g} / \mathrm{L}$, the mud YP and AV increased more sharply. This is possibly due to the formation of gel at relatively high WLG concentration.

Figure 4 compares the effects of WLG and CMC on mud properties. The addition of CMC resulted in mild increases in mud viscosity and yield point, while WLG is much more effective in thickening mud. Mud filtration test 


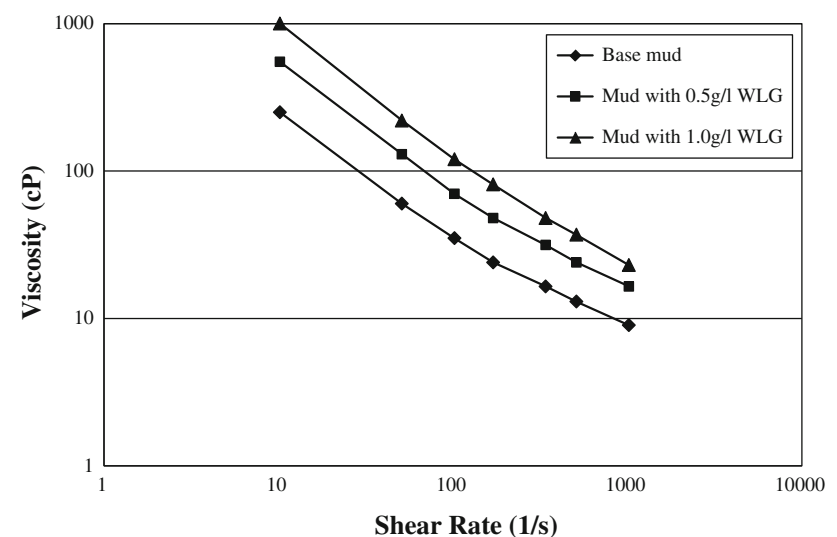

Fig. 2 Effect of shear rate and WLG concentration on mud viscosity

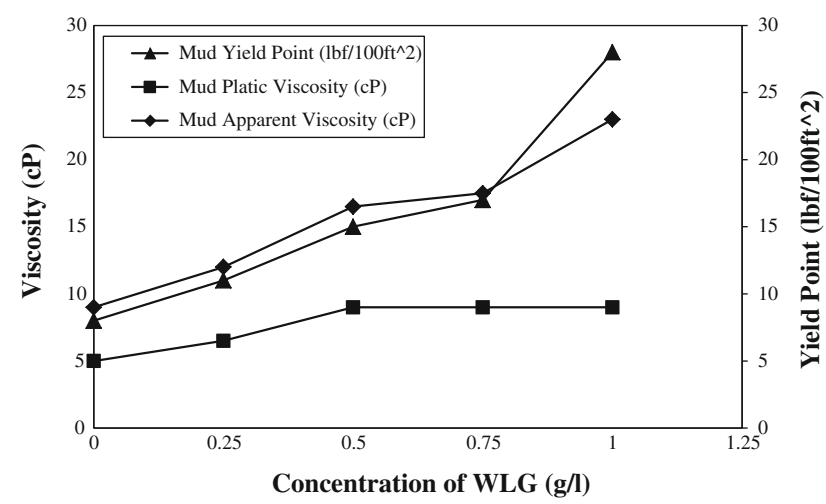

Fig. 3 Effect of WLG concentration on mud properties

was also conducted on WLG mud. Excessive filtrate loss during drilling can result in wellbore instability. Mud filtrate is often incompatible with formation fluid and can cause formation damage. The base mud without WLG had a filtrate of $10 \mathrm{~mL}$ after $7.5 \mathrm{~min}$, while the mud containing $1 \mathrm{~g} / \mathrm{L}$ WLG had a filtrate of $9 \mathrm{~mL}$. WLG has no significant effect on filtrate loss.

The mud containing $1 \mathrm{~g} / \mathrm{L}$ WLG was heated to $70{ }^{\circ} \mathrm{C}$ for $30 \mathrm{~min}$, to test the stability of WLG at elevated temperature. The test data in Fig. 5 show good stability of WLG at high temperature. The mud properties after heating remained almost unchanged.

The mud samples were also tested for long-term stability under high temperature. The mud samples aged at $85^{\circ} \mathrm{C}$ for $6 \mathrm{~h}$, then cooled down to room temperature and mud properties were measured. The test data are presented in Table 3. For the mud containing WLG, both mud YP and AV increased after aging. This is probably due to the formation of weak gel at high temperature. On the other hand, the mud containing CMC showed reduction in YP and AV after aging. Comparison shows WLG is resilient to long-term heating.

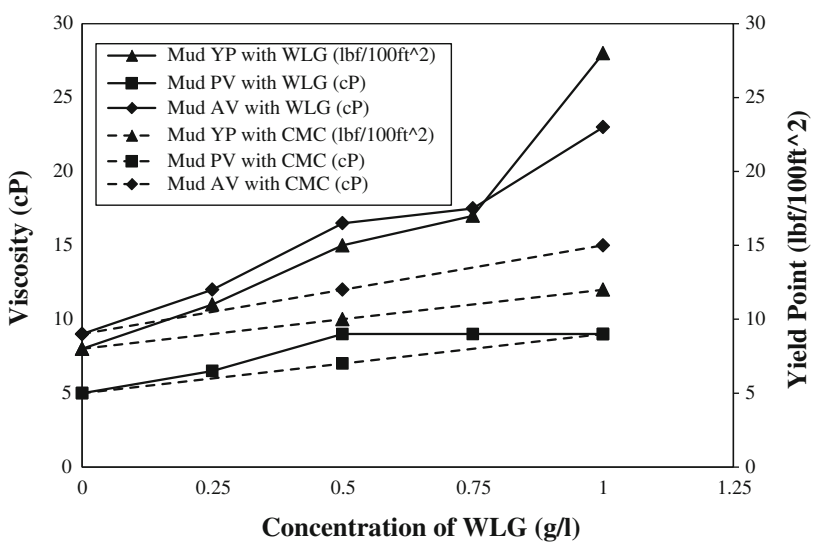

Fig. 4 Comparison of WLG mud and CMC mud

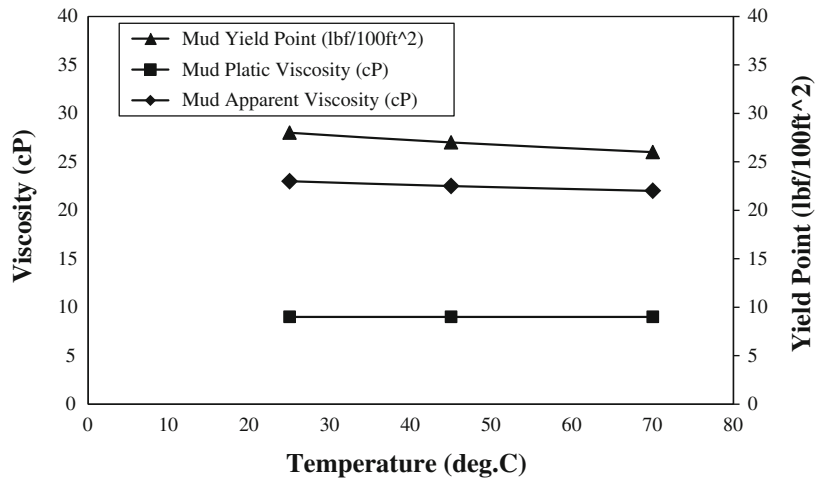

Fig. 5 Behavior of WLG mud at elevated temperature

Table 3 Properties of mud after aging tests

\begin{tabular}{|c|c|c|c|c|}
\hline Tested fluid & Test condition & $\begin{array}{l}\mathrm{PV} \\
(\mathrm{cP})\end{array}$ & $\begin{array}{l}\text { YP }(\mathrm{lb} / \\
\left.100 \mathrm{ft}^{2}\right)\end{array}$ & $\begin{array}{l}\mathrm{AV} \\
(\mathrm{cP})\end{array}$ \\
\hline $\begin{array}{l}\text { Base } \\
\text { mud }+0.5 \mathrm{~g} \\
\text { WLG }\end{array}$ & $25^{\circ} \mathrm{C}$ & 9 & 28 & 23 \\
\hline $\begin{array}{l}\text { Base } \\
\text { mud }+0.5 \mathrm{~g} \\
\text { WLG }\end{array}$ & $\begin{array}{l}\text { Aged at } 85^{\circ} \mathrm{C} \text { for } 6 \mathrm{~h} \text { then } \\
\text { cool to } 25^{\circ} \mathrm{C}\end{array}$ & 9 & 39 & 29 \\
\hline $\begin{array}{l}\text { Base } \\
\operatorname{mud}+0.5 \mathrm{~g} \\
\text { CMC }\end{array}$ & $25^{\circ} \mathrm{C}$ & 9 & 12 & 15 \\
\hline $\begin{array}{l}\text { Base } \\
\text { mud }+0.5 \mathrm{~g} \\
\mathrm{CMC}\end{array}$ & $\begin{array}{l}\text { Aged at } 85^{\circ} \mathrm{C} \text { for } 6 \mathrm{~h} \text { then } \\
\text { cool to } 25^{\circ} \mathrm{C}\end{array}$ & 8 & 8 & 12 \\
\hline
\end{tabular}

A good mud thickener must maintain stable viscosity under the attack of sodium and calcium ions. $\mathrm{NaCl}$ and $\mathrm{CaCl}_{2}$ were mixed into WLG mud and the mud properties were measured. The test results are shown in Figs. 6 and 7. It can be seen that WLG is resilient to both sodium and calcium ions. The key parameters (YP, $\mathrm{AV}$ and $\mathrm{PV}$ ) all remained quite stable after addition of salts.

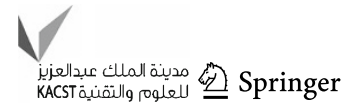




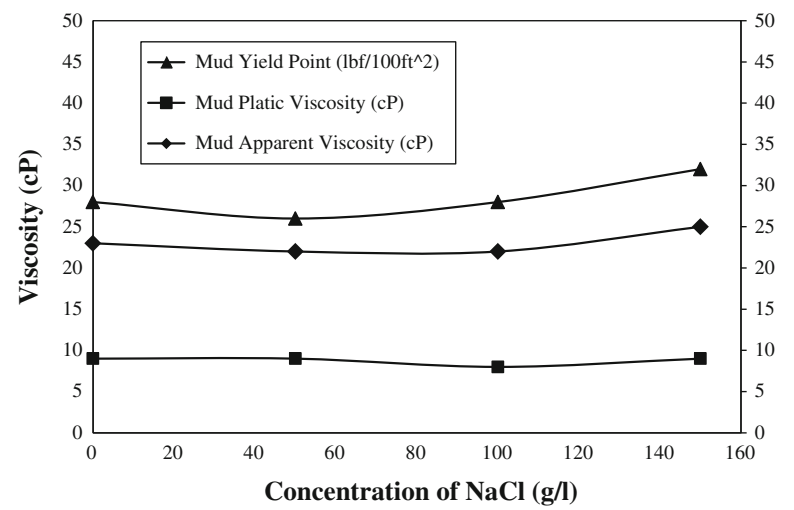

Fig. 6 Stability of WLG mud at varied concentrations of $\mathrm{NaCl}$

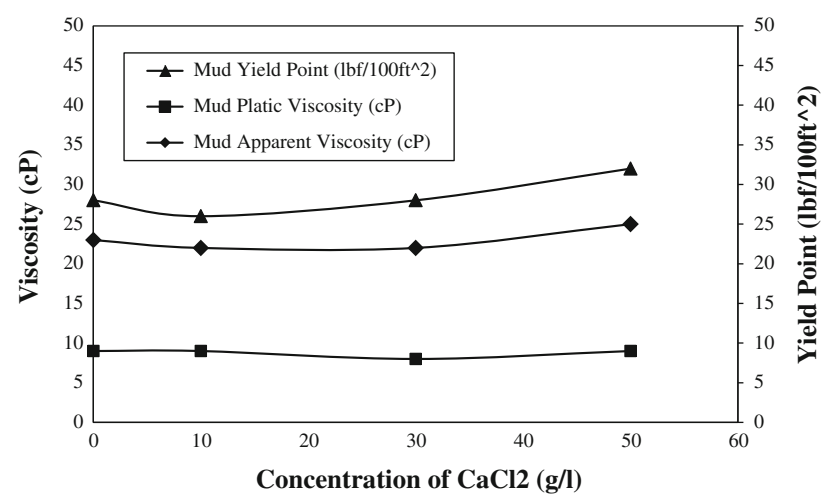

Fig. 7 Stability of WLG mud under varied concentrations of $\mathrm{CaCl}_{2}$

\section{Conclusions}

Welan Gum is excellent as mud thicker, but not effective in reducing mud filtrate loss. Compared with CMC, WLG is more effective in boosting mud viscosity. WLG mud maintains stable viscosity under high temperature and long-term heating. Sodium and calcium ions have minor influence on WLG mud viscosity.

Open Access This article is distributed under the terms of the Creative Commons Attribution License which permits any use, distribution, and reproduction in any medium, provided the original author(s) and the source are credited.

\section{References}

Allen F, Best G, Lindroth T (1991) Welan gum in cement compositions. United States Patent 5004506

Bourgoyne A, Chenevert M, Millheim K, Yang F (1986) Applied drilling engineering. SPE Textbook Series, Richardson, pp 40-50

Chen F (2007) Study of factors affecting property of welan gum solution. Food Sci 28(9):49-52

Gao C (2013) Viscosity of HPAM under shearing and heat. J Petrol Explor Prod Technol 3(3):203-206

Hoskin D, Mitchell T, Shu P (1991) Oil reservoir permeability profile control with cross linked welan gum biopolymers. United States Patent 4991652

Rabia H (1985) Oilwell drilling engineering. Graham and Trotman, London, pp 105-130

Rakitsky W, Richey D (1992) Rapidly hydrating welan gum. United States Patent 5175277 